\section{Anion-exchange enrichment and spectrophotometric determination of traces of uranium in sea water}

\section{R. Kuroda, Y. Hayashibe, K. Oguma, and K. Kurosu}

Laboratory for Analytical Chemistry, Faculty of Engineering, University of Chiba, Chiba 260, Japan

\section{Anreicherung durch Anionenaustausch und spektral- photometrische Bestimmung von Uranspuren in Meereswasser}

The determination of $U$ in sea water generally entails a concentration step. High concentrations of $\mathrm{NaCl}$ in sea water makes it difficult to achieve quantitative recovery of $U$ by conventional ion-exchange techniques [1]. We found that the anion-exchange in $\mathrm{Mg}\left(\mathrm{NO}_{3}\right)_{2}$ media [2] permits enrichment of $\mathrm{U}$ even in the presence of high concentrations of $\mathrm{NaCl}$, providing the basis for the determination of $\mathrm{U}$ in sea water.

\section{Experimental}

Procedure. Filter the sea water sample (acidified to $0.1 \mathrm{~mol} / 1$ in $\mathrm{HNO}_{3}$ ) through a $0.45 \mu \mathrm{m}$ membrane filter. Take a $200 \mathrm{ml}$ fraction of the filtrate and add $220 \mathrm{~g}$ of $\mathrm{Mg}\left(\mathrm{NO}_{3}\right)_{2} \cdot 6 \mathrm{H}_{2} \mathrm{O}$ to it. Condition the anion-exchange column ( $2 \mathrm{~g}$ of Bio-Rad AG1-X8(Cl) contained; $12 \mathrm{~mm}$ i.d. $\times 28 \mathrm{~mm}$ ) with $20 \mathrm{ml}$ of $2.5 \mathrm{~mol} / 1 \mathrm{Mg}\left(\mathrm{NO}_{3}\right)_{2}-0.5 \mathrm{~mol} / 1 \mathrm{NaCl}-0.1 \mathrm{~mol} / 1 \mathrm{HNO}_{3}$ solution. Load the sample solution on to the column at a flow rate of $2 \mathrm{ml}$ $\mathrm{min}^{-1}$. Pass $30 \mathrm{ml}$ of $6 \mathrm{~mol} / 1 \mathrm{HCl}$ to remove Th. Strip U with

Offprint requests to: $\mathrm{R}$. Kuroda
$15 \mathrm{ml}$ of $1 \mathrm{~mol} / 1 \mathrm{HCl}$ and determine photometrically with Arsenazo III.

\section{Results and discussion}

The distribution coefficients of U(VI) in $0.5 \mathrm{~mol} / \mathrm{l} \mathrm{NaCl}$ $0.1 \mathrm{~mol} / \mathrm{l} \mathrm{HNO}_{3}$ solution are obtained by a batch equilibrium study as a function of $\mathrm{Mg}\left(\mathrm{NO}_{3}\right)_{2}$ concentration. The coefficients obtained are $1800,610,210,46,13$, and 4 for $3.0,2.5,2.0,1.5$, 1.0 , and $0.5 \mathrm{~mol} / 1 \mathrm{Mg}\left(\mathrm{NO}_{3}\right)_{2}$ concentrations, respectively. These values are higher than those obtained in the absence of $\mathrm{NaCl}$ [2], favourable for the sorption of $U$ from sea water. Artificial sea water $\left(4.6 \mu \mathrm{g} \mathrm{U}^{-1}\right)$ was analyzed for $\mathrm{U}$ to confirm the procedure; the average recovery obtained was $102 \pm 2.0 \%$ $(n=3)$. Possible interferences from Th, which is also sorbed from the nitrated media, can be avoided by simply washing the column with $6 \mathrm{~mol} / 1 \mathrm{HCl}$ before the elution of $\mathrm{U}$. The results of sea water analyses with and without addition tests were $3.54 \pm 0.10 \mu \mathrm{g} \mathrm{U}^{-1}$ (Amatsukominato, Pacific Ocean, salinity $32.20 \% ; n=6$ ) and $3.01 \pm 0.20 \mu \mathrm{g} \mathrm{U}{ }^{-1}$ (Aburatsubo bay, Kanagawa, salinity $30.24 \% \circ ; n=9$ ). No difference was found in the $U$ results whether the acidification of the water sample with $\mathrm{HNO}_{3}$ was made before or after the filtration of the collected samples.

\section{References}

1. Kuroda R, Oguma K, Mukai N, Iwamoto M (1987) Talanta $34: 433-434$

2. Kuroda R, Seki T (1980) Fresenius Z Anal Chem 300:107111

Received March 11, 1989; revised April 26, 1989

\section{Benzoin oxime as a reagent for the separation of rhenium from Mo, W, $\mathrm{V}$ and others}

Sirpal Khaira (nee Saikhon) and L. R. Kakkar

Department of Chemistry, Kurukshetra University, Kurukshetra - 132119 (Haryana), India

\section{Benzoinoxim als Reagens zur Trennung des Rheniums von Mo, W, $V$ und anderen}

Amongst the oximes, dimethylglyoxime, $\alpha$-furildioxime and salicylaldoxime have oftenly been used for extractive studies of transition metals in acid as well as alkaline media [1]. Though the highly specific nature of benzoin oxime as a gravimetric reagent [2] for molybdenum has long been known, there is, however, hardly any report available in literature which makes use of this reagent for the extractive separation of rhenium particularly from elements of analytical importance. Keeping this fact in view, a systematic investigation is desirable.

Experimental. To the sample solution containing $100 \mu \mathrm{g} \mathrm{Re}$ and milligram amounts of other ions in a separatory funnel are added $4 \mathrm{ml} 10 \mathrm{~mol} / 1 \mathrm{HCl}, 1 \mathrm{ml} \mathrm{SnCl}{ }_{2} \cdot 2 \mathrm{H}_{2} \mathrm{O}(20 \%)$ and $2 \mathrm{ml}$ $1 \% \alpha$-benzoin oxime solution in alcohol in a final $20 \mathrm{ml}$ volume

Offprint requests to: L. R. Kakkar and the rhenium complex thus formed is extracted once with an equal volume of chloroform for $3 \mathrm{~min}$. The metal ion from the solvent is back-extracted with $1: 1 \mathrm{NH}_{3}$ containing a few drops of $30 \% \mathrm{H}_{2} \mathrm{O}_{2}$. When $\mathrm{Mo}(\mathrm{VI})$ and $\mathrm{W}(\mathrm{VI})$ are also present in the sample, $\sim 100 \mathrm{mg} \mathrm{NaF}$ are added initially to the aqueous solution. Microgram amounts of rhenium are determined by the thiocyanate method [3] and the presence or absence of other metal ions is tested by sensitive conventional methods [4].

It has been observed that rhenium in lower valency state, produced on reduction with stannous chloride, forms a colourless complex with $\alpha$-benzoin oxime in hydrochloric acid solution which is highly extractable into chloroform. The extraction is influenced by various parameters, namely, acidity, reductant, reagent concentration etc. (Table 1) and under the optimum conditions chosen for the system, rhenium is transferred quantitatively into the solvent phase in a single extraction.

$\mathrm{U}(\mathrm{VI}), \mathrm{V}(\mathrm{V}), \mathrm{Cr}(\mathrm{III}), \mathrm{Cd}(\mathrm{II})(0.25 \mathrm{mg} / \mathrm{ml}) ; \mathrm{Fe}(\mathrm{II}), \mathrm{Ni}(\mathrm{II})$, $\mathrm{Co}(\mathrm{II}), \mathrm{Cu}(\mathrm{II}), \mathrm{Mn}(\mathrm{II})(0.5 \mathrm{mg} / \mathrm{ml}) ; \mathrm{Cr}$ (VI), $\mathrm{Zr}(\mathrm{IV})(0.1 \mathrm{mg} / \mathrm{ml})$ do not interfere at all. Mo(VI) and W(VI) $(0.5 \mathrm{mg} / \mathrm{ml})$ are extracted only in traces, but the interference due to these ions is eliminated by masking with $\sim 100 \mathrm{mg}$ of NaF. $\mathrm{SO}_{4}^{2-}, \mathrm{PO}_{4}^{3-}$, $\mathrm{F}^{-}$do not influence the extraction; whereas $\mathrm{Cl}^{-}, \mathrm{C}_{2} \mathrm{O}_{4}^{2-}$, $\mathrm{CH}_{3} \mathrm{COO}^{-}$and tartrate decrease it by $1,5,5$ and $8 \%$, respectively.

The ratio of metal to ligand in the complex formed is determined as $1: 6$ by conductometric titrations [5] using equimolar solutions of rhenium and $\alpha$-benzoin oxime with concentrations of 0.004 and $0.005 \mathrm{~mol} / 1$ in each set, respectively. 